\title{
The EU Return Directive - Retour à la «case départ»?
}

Sarah Progin-Theuerkauf*

The EU Return Directive has been adopted 10 years ago. The following article analyzes whether the system that has been created has met the objectives set in 2008. It will especially focus on shortcomings hat can be illustrated by CJEU judgments. The 2018 proposal for a recast of the Directive will also be studied. The article comes to the conclusion that it will be inevitable to go back to the start and think about a better legal regime tackling the issue of returning irregular migrants.

I. Introduction 33

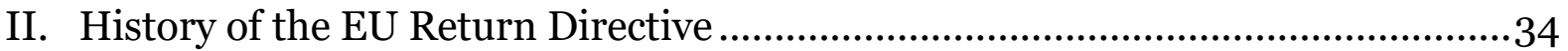

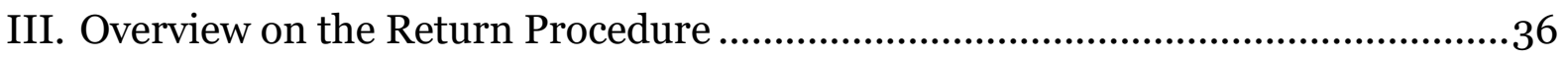

IV. Selected Problematic Issues ................................................................... 37

1. Relationship Return - Criminal Proceedings............................................. 37

2. Relationship Asylum Procedure - Return Procedure ...................................39

3. Right to be Heard ........................................................................... 41

4. Detention and Detention Conditions ....................................................42

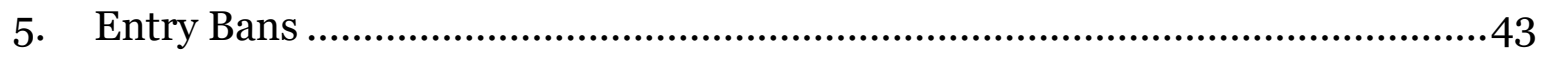

6. Fate of «Non Removable» Returnees .........................................................44

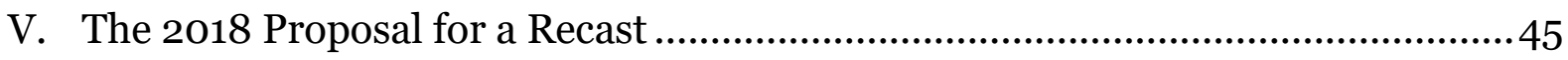

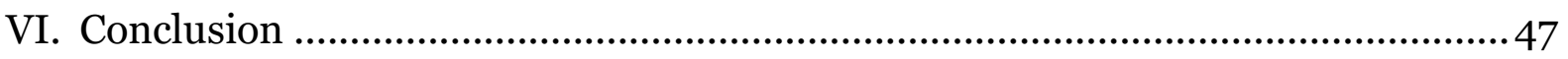

Citation: $\quad$ Sarah Progin-Theuerkauf, The EU Return Directive - Retour à la «case depart»?, in: sui-generis 2019, S. 32

URL: $\quad$ sui-generis.ch/91

DOI: $\quad$ https://doi.org/10.21257/sg.91

* Sarah Progin-Theuerkauf is a Full Professor for EU Law and Migration Law at the University of Fribourg, sarah.progin-theuerkauf@unifr.ch. 


\section{Introduction 1}

1 The «Directive on common standards and procedures in Member States for returning illegally staying third-country nationals»² (in the following: «EU Return Directive» or «the Directive») was adopted by the European Parliament and the Council ten years ago. It is now time to reflect on the experiences with the Directive and possible adaptions to be made. Was it a success or rather a failure? Does the regime foreseen by the Directive really work? If there are aspects to criticize, how shall the future EU return regime look like? Will the Commission proposal of September $2018^{3}$ remedy critical aspects? The following article will try to answer these questions.

According to its Recital 4, the Directive is supposed to fix «clear, transparent and fair rules [...] to provide for an effective return policy». The more than 20 cases decided by the Court of Justice of the European Union (CJEU) interpreting provisions of the Directive4 seem to speak a different language: The Directive has demonstrably failed to simplify or considerably accelerate return procedures. Likewise, it did not provide for a satisfactory level of protection of fundamental rights of irregular migrants during these procedures. Many provisions of the Directive are far from being clear and needed interpretation by the CJEU.

1 This article is an updated and extended version of a Working Paper written for the NCCR On the Move: Sarah Progin-Theuerkauf, Return Me - If You Can. 10th Anniversary of the Adoption of the EU Return Directive - A Success Story?, 2018.

2 Directive 2008/115/EC of the European Parliament and of the Council of 16 December 2008 on common standards and procedures in Member States for returning illegally staying third-country nationals.

$3 \operatorname{COM}(2018) 634$ final; see infra, V.

See infra, IV.
3 Moreover, the return track record of the Member States of the past years is rather weak. 5 Many of the third-country nationals ordered to leave actually do not return to their country of origin. A lot of them prefer to abscond and probably still live as irregular migrants somewhere in Europe, which makes them an easy prey for exploitation.

4 In 2017, 516'115 third-country nationals were ordered to leave the European Union, compared to $493^{\prime} 785$ persons in 2016 and 533'395 persons in 2015. In 2017,214 ' 150 third-country nationals effectively returned to their country of origin, against 226'150 in 2016 and 196 ' 180 in 2015 . The total return rate was $41.5 \%$ in $2017^{6}, 45.8 \%$ in 2016 and $36.78 \%$ in 2015.7 This makes an average return rate of just a little over $40 \%$ in the past three years. If countries in the Western Balkan, where readmission agreements exist and work well, are taken out of these statistics, the return rates drop even further.

5 See the available data.

6 The rate for 2017 is based on the author's own calculation with the help of the most recent Eurostat data. In its communication of 4 December 2018, the European Commission mentions a return rate of $36.6 \%$ in 2017, and 188'905 persons returned. See Communication from the Commission to the European Parliament, the European Council, and the Council on managing migration in all its aspects: progress under the European Agenda on Migration, COM(2018) 798 final.

7 See Annex to the Communication from the Commission to the European Parliament, the European Council and the council on managing migration in all its aspects: progress under the $\mathrm{Eu}-$ ropean Agenda on Migration, COM(2018) 798 final and Annex to the report from the Commission to the European Parliament, the European Council and the council about the Progress report on the European Agenda on Migration - Returns (COM2017 669 final). 
Different factors may explain this rather low number of returns: Besides the legal problems that will be discussed in this article, a high number of practical problems has arisen that the law cannot really influence, for example the existence (or absence) of financial and human resources to enforce returns and more cooperation among the Member States. Irregular migrants themselves are not willing to return to their country of origin and prefer to hide and try their luck elsewhere. Last but not least, one decisive factor for a successful return policy is almost completely out of the hands of the EU and its Member States: the (lack of) cooperation with third countries supposed to take back their own nationals. ${ }^{8}$

6 The effective return of irregular migrants is an important element of the European Agenda on Migration. ${ }^{9}$ Indeed, an effective return policy is considered to be a cornerstone of a comprehensive migration policy. ${ }^{10}$ In order to be credible, an exclusive system based on selection (which there seems to be a broad consensus for in the EU) must also be able to remove undesired migrants. However, it is not an easy task to put pressure on countries of origin: Therefore, the EU must take into account the specific situation of the main countries of origin. Realistically, readmission agreements must

$8 \overline{\text { See Communication from the Commission to the }}$ European Parliament, the European Council, and the Council on managing migration in all its aspects: progress under the European Agenda on Migration, COM(2018) 798 final.

9 See Communication from the Commission to the European Parliament, the council, the European Economic and Social Committee and the Committee of the Regions on a European Agenda on migration, $\mathrm{COM}$ (2015) 240 final.

10 See Carsten Hörich 2011, Die Rückführungsrichtlinie: Entstehungsgeschichte, Regelungsgehalt und Hauptprobleme, ZAR 9/2011, 281. be linked to some advantages for the countries of origin, for instance visa liberalization, a legal migration program, economic cooperation and/or direct financial aid.

\section{History of the EU Return Directive}

7 After long and laborious debates, Directive 2008/115/EC «on common standards and procedures in Member States for returning illegally staying thirdcountry nationals» was adopted by the Parliament and the Council on 16 December 2008 and published as a «Christmas present» 11 in the Official Journal of the European Union on 24 December 2008.12 The Directive marked a turning point in EU migration policy history, as before 2008, there simply was no EU return policy. Returns were a matter of domestic law. On a European level, the existing tools only aimed at facilitating cooperation among the Member States. ${ }^{13}$

8 The legal basis for the Directive was Article 63(3)(b) of the Treaty on the European Community (now Article 79 (2) (c) TFEU). It is worth mentioning that the Directive

$11 \overline{\text { See Francesco Maiani, Directive de la honte ou }}$ instrument de progrès ? - Avancées, régressions et statu quo en droit des étrangers sous l'influence de la Directive sur le retour, in : Epiney/ Gammenthaler (eds.), Schweizerisches Jahrbuch für Europarecht 2008/2009, 2009, 289.

12 Directive 2008/115/EC of the European Parliament and of the Council of 16 December 2008 on common standards and procedures in Member States for returning illegally staying third-country nationals.

13 See Council Directive 2001/40/EC of 28 May 2001 on the mutual recognition of decisions on the expulsion of third-country nationals, OJ L 149, 2.6.2001, p. 34-36, or Council Decision 2004/573/EC of 29 April 2004 on the organisation of joint flights for removals from the territory of two or more Member States, of third-country nationals who are subjects of individual removal orders, OJ L 261, 6.8.2004, p. 28-35. 
is not an instrument in the area of asylum law, but applies to all third-country nationals illegally staying in the territory of the Member States (Article 2 (1) of the Directive). There is a multitude of reasons for the illegal stay: illegal entry, the withdrawal or non-renewal of a residence permit due to unemployment or divorce, expiry of a visa, a rejected asylum claim, etc.

9 The adoption of the Directive triggered many debates among NGOs and academics. Some authors called it the «Directive of shame»14, either because they argued that the Directive set an «inexcusably low» standard for returns (in terms of the protection of rights of the concerned migrants), or because they thought EU legislation on the issue of returns was not necessary, as this meant that more liberal approaches in certain Member States (tolerating the presence of irregular migrants) were not possible anymore. Ever since its existence, the Directive was criticized for its unclear wording and its

14 For further references see Fabian Lutz, The Negotiations on the Return Directive, 2010; Anneliese Baldaccini, The EU Directive on Return: Principles and Protest, Refugee Survey Quarterly Vol. 28 (2009), Issue 4, 114-138; Anneliese Baldaccini, The return and removal of irregular migrants under EU law: An analysis of the Returns Directive, EJML Vol. 11(2009), Issue 1, 1-17; Diego Acosta, The Good, the Bad and the Ugly in EU Migration Law: Is the European Parliament Becoming Bad and Ugly? (The Adoption of Directive 2008/15: The Returns Directive), EJML Vol. 11 (2009) Issue 1, 19-39; Pieter Boeles et al. (eds.), European Migration Law, $2^{\text {nd }}$ ed., 2014, 385 et seq.; Steve Peers et al. (eds.), EU immigration and asylum law : text and commentary, 2nd ed., Vol. 2 : EU Immigration Law, 2012, 483 et seq.; Francesco Maiani, (Fn. 10). See also Steve Peers, The EU's Returns Directive: Does it improve or worsen the lives of irregular migrants?, 28.3.2014. problematic interference with fundamental rights. ${ }^{15}$

10 The deadline for implementing the Directive expired on 24 December 2010. In March 2014, the Commission published a first evaluation of the EU Return Directive. ${ }^{16}$ In its communication, the Commission mentions five areas in which implementation of the Directive by the Member States was either incomplete or varied considerably from one Member State to another: detention, voluntary departure and monitoring of forced return, safeguards and remedies, criminalization of irregular entry and stay and the launch of return procedures and entry bans.

In order to provide guidance to Member States' authorities when carrying out return related tasks, the Commission adopted a first version of the common

15 Carsten Hörich, (Fn. 9); Julian Augustin, Die Rückführungsrichtlinie der Europäischen Union, 2016 ; Marcus Bergmann/ Carsten Hörich, Das Ausländerstrafrecht auf dem Prüfstand: Rückführungsrichtlinie und EuGH-Rechtsprechung, in: Barwig et al. (Hrsg.), Steht das europäische Migrationsrecht unter Druck?, 2015, 17 ff.; MarenKathrin Diekmann, Menschenrechtliche Grenzen des Rückführungsverfahrens in Europa, 2016; Catherine Haguenau-Moizard, La pénalisation du séjour irrégulier en droit européen, en droit français et en droit suisse, in: Breitenmoser/Gless/Lagodny (Hrsg.), Schengen und Dublin in der Praxis, Aktuelle Fragen, 2015, 169 ff.; Carsten Hörich, Abschiebungen nach europäischen Vorgaben, 2015; Fabian Lutz / Sergo Mananashvili, in: Hailbronner/Thym, EU Immigration and Asylum Law, A Commentary, Second Edition, 2016, $658 \mathrm{ff}$.

16 European Commission, Communication from the Commission to the Council and the European Parliament on EU Return Policy, COM(2014) 199 final; there Part IV. 
«Return Handbook»17 in 2015. An updated version was published in September 2017..$^{18}$ In September 2018, the Commission proposed a recast of the EU Return Directive. ${ }^{19}$

\section{Overview on the Return Procedure}

12 The current regime set up by the EU Return Directive foresees three steps:

1. Member States are obliged to issue a return decision.

2. The return decision shall provide for an appropriate period for voluntary departure.

3. If the third-country national does not depart, the return decision has to be enforced. Member States may use coercive measures to carry out the removal.

According to Article 6 (1) of the Directive, Member States are obliged to issue a return decision to any third-country national staying illegally in their territory. Exceptions to this principle are set up by Article 6 (2) to (5).

14 Before adopting a return decision, Member States must take into account the details of the third-country national's family life, and in particular the interests of a minor child of that third-country national (Article 5), unless such details could

$17 \overline{\text { European Commission, Recommendation Estab- }}$ lishing a common « Return Handbook » to be used by Member Sates' competent authorities when carrying out return related tasks, C(2015) 6250 - Annex.

18 European Commission, Recommendation Establishing a common « Return Handbook » to be used by Member Sates' competent authorities when carrying out return related tasks, C(2017) 6506 - Annex.

$19 \operatorname{COM}(2018) 634$ final; see infra $\mathrm{V}$. have been provided earlier by the person concerned. ${ }^{20}$

15 Member States always have the possibility to grant a residence permit or other authorization offering a right to stay. However, the Directive does not create new obligations for the Member States to grant residence permits to irregular migrants. ${ }^{21}$ So far, there is no EU-wide rule on the regularization of irregular migrants. It is also clear that Member States are not allowed to simply tolerate the presence of illegally staying third-country nationals in their territory, which leaves them with two possibilities: either granting a right to stay or launching a return procedure. ${ }^{22}$ In order to avoid grey zones, there is no third option. ${ }^{23}$

16 A return decision shall provide for an appropriate period for voluntary departure (Article $7[1]$ ). If there is a risk of absconding, or if an application for a legal stay has been dismissed as manifestly unfounded or fraudulent, or if the person concerned poses a risk to public policy, public security or national security, Member States may refrain from grant-

$20 \overline{\text { CJEU judgement of 8. May 2018, C-82/16, K.A. }}$ ECLI:EU:C:2018:308, para. 107.

21 European Commission, Recommendation Establishing a common «Return Handbook » to be used by Member Sates' competent authorities when carrying out return related tasks, C(2017) 6506 - Annex, p. 65 (13.2.). See also CJEU judgement of 5. June 2014, C-146/14, Mahdi, ECLI:EU:C:2014:1320, paras. 87 and 88.

22 European Commission, Recommendation Establishing a common «Return Handbook » to be used by Member Sates' competent authorities when carrying out return related tasks, C(2017) 6506 - Annex, p. 19 (5.).

23 European Commission, Recommendation Establishing a common « Return Handbook » to be used by Member Sates' competent authorities when carrying out return related tasks, C(2017) 6506 - Annex, p. 20 (5.). 
ing a period for voluntary departure, or may grant a period shorter than seven days (Article 7 [4]).

If no period for voluntary departure has been granted or if the obligation to return has not been complied with within the period for voluntary departure, Member States shall take all necessary measures to enforce the return decision (Article 8 [1]).

Member States may use force to remove the irregular migrant, but the principle of proportionality must be respected: Article 8 (4) states that where «Member States use as a last resort - coercive measures to carry out the removal of a third-country national who resists removal, such measures shall be proportionate and shall not exceed reasonable force».

19 Return decisions shall be accompanied by an entry ban if no period for voluntary departure has been granted or if the obligation to return has not been complied with (Article 11). The length of the entry ban shall not exceed five years (Article 11 [1]).

Detention is possible if there is a risk of absconding or if the third-country national concerned avoids or hampers the preparation of return or the removal process (Article 15 [1]). However, according to Article 16, detention shall take place, as a rule, in specialized detention facilities. In any case, third-country nationals shall be kept separated from ordinary prisoners.

\section{Selected Problematic Issues}

\section{Relationship Return - Criminal Proceedings}

21 In several cases already decided by the CJEU, the relationship between the return procedure and criminal proceedings has been clarified. ${ }^{24}$ The Court has emphasized that, in principle, criminal legislation and the rules of criminal procedure fall within the competence of the Member States 25 and that Member States are thus free to criminalize illegal entry or stay. However, any Member State measure that endangers the «effet utile» of the Directive, which means that it is likely to delay the return, is incompatible with the Directive. Therefore, Member States must adjust their legislation in the area of illegal immigration and illegal stays in order to ensure compliance with the Return Directive. ${ }^{26}$ They are not allowed to apply rules which jeopardize the

24 CJEU judgment of 28 April 2011, C-61/11 PPU, El Dridi, ECLI:EU:C:2011:268; CJEU judgment of o6 December 2011, C-329/11, Achughbabian, ECLI:EU:C:2011:807; judgement of o6 December 2012, C- 430/11, Sagor, ECLI:EU:C:2012:777; CJEU judgement of 21 march 2013, C-522/11, Mbaye, ECLI:EU:C:2013:190; CJEU judgement of O3 July 2014, C-189/13, da Silva, ECLI:EU:C:2014:2043; CJEU judgement of 23 April 2015, C-38/14, Zaizoune, ECLI:EU:C:2015:260; CJEU judgement 01 October 2015, C-290/14, Celaj, ECLI:EU:C:2015:640; CJEU judgement O7 June 2016, C-47/15, Affum, ECLI:EU:C:2016:408. See also Marcus Bergmann/ Carsten Hörich, (Fn. 14); Catherine Haguenau-Moizard, (Fn. 14); Thomas Hugi Yar, Das Urteil El Dridi, die EU-Rückführungsrichtlinie und der Schengen-Besitzstand, Jusletter vom 11. Juli 2011; Thomas Hugi Yar, EuGH, Rs. C-61/11, Hassen El Dridi (alias Soufi Karim), Asyl 3/11, 30 f.; Sarah Progin-Theuerkauf, Zur Auslegung der Begriffe der «Massnahmen» und «Zwangsmassnahmen» in Art. 8 Abs. 1 und 4 der EURückführungsrichtlinie, Kommentar zu EuGH, Rs. C-329/11, Achughbabian, ASYL 2/12, $36 \mathrm{ff}$.

25 CJEU judgment of o6 December 2011, C-329/11, Achughbabian, ECLI:EU:C:2011:807, para. 33.

26 CJEU judgement of 28. April 2011, C-61/11 PPU, El Dridi, ECLI:EU:C:2011:268, para. 54. 
achievement of the objectives pursued by the Directive, e.g. rules that hinder a rapid return to the country of origin.

Based on the cases already decided by the Court, the following principles must be respected:

- If illegal entry or stay are criminal offences, they may be sanctioned by fines, but not by a custodial sentence. ${ }^{27}$ The Member States must rather pursue their efforts to enforce the return decision. If the thirdcountry national has not yet been subject to the coercive measures referred to in Article 8 of the Directive or has not, if placed in detention with a view to the preparation and carrying out of his removal, yet reached the end of the maximum term of that detention, he may not be imprisoned for the illegal stay. 28

- The sanctioning of other criminal offences (than illegal entry or stay) by a prison sentence is compatible with the Directive.

- It is not possible to sanction illegal stay by either a fine or a removal (if the two measures are mutually exclusive). ${ }^{29}$ The Directive obliges the Member States to always adopt a return decision.

- If the return procedure has failed or if the third-country national has returned to the Member State by vio-

CJEU judgement of 28. April 2011, C-61/11 PPU, El Dridi, ECLI:EU:C:2011:268, para. 58.

28 CJEU judgment of o6 December 2011, C-329/11, Achughbabian, ECLI:EU:C:2011:807, para. 50 ; CJEU judgement 07 June 2016, C-47/15, Affum, ECLI:EU:C:2016:408, para. 52.

29 CJEU judgement of 23 April 2015, C-38/14, Zaizoune, ECLI:EU:C:2015:260. lating an entry ban, prison sentences are compatible with the Directive. 30 The Directive does not preclude penal sanctions being imposed on third-country nationals to whom the return procedure established by the Directive has been applied and who are illegally staying in the territory of a Member State without there being any justified ground for non-return. ${ }^{31}$ However, if a third-country national never leaves the respective Member State, he or she is in an unlawful situation as a consequence of an initial illegal stay, and not as a consequence of a subsequent illegal stay resulting from a breach of an entry ban. The general rule that criminal penalties for initial illegal stays are not permitted, therefore still applies. ${ }^{32}$

- An expulsion or removal order, which predates by five years or more the date on which the Return Directive was implemented in the Member State, cannot be used as a basis for subsequent criminal proceedings. 33

23 As the case-law on the issue is now abundant, it would make sense to synthesize and integrate it into a Recast Return Directive which has not been done by the EU Commission in its 2018 proposal (see below).

30 CJEU judgement 01 October 2015, C-290/14, Celaj, ECLI:EU:C:2015:640; CJEU judgement of 28. April 2011, C-61/11 PPU, El Dridi, ECLI:EU:C:2011:268, para. 60; CJEU judgment of o6 December 2011, C-329/11, Achughbabian, ECLI:EU:C:2011:807, para. 50.

31 CJEU judgement 07 June 2016, C-47/15, Affum, ECLI:EU:C:2016:408, para. 54 ; CJEU judgment of o6 December 2011, C-329/11, Achughbabian, ECLI:EU:C:2011:807, para. 50.

32 CJEU judgement of 26 July 2017, C-225/16, Ouhrami, ECLI:EU:C:2017:590, paras. 55 et seq.

33 CJEU judgement of 19 September 2013, C297/12, Filev and Osmani, ECLI:EU:C:2013:569, para. 56. 


\section{Relationship Asylum Procedure - Return Procedure}

24 In principle, an ongoing asylum procedure excludes the execution of a return decision (recital 9). The return procedure, if it has already been initiated before the deposit of an asylum application, must be suspended until the first instance decision. The CJEU has confirmed and emphasized this principle in two judgments. 34

According to Article 9 of the 2013 Asylum Procedures Directive35, applicants shall be allowed to remain in the Member State until the determining authority has made a decision in accordance with the procedures at first instance. However, that right to remain shall not constitute an entitlement to a residence permit. Article 9(2) foresees only two exceptions: Where a person makes a subsequent application (Articles 40 and 41 of the Directive) or where the authorities will surrender or extradite a person either to another Member State pursuant to obligations in accordance with a European arrest warrant or otherwise, or to a third country or to international criminal courts or tribunals.

Article 46(5) of the Asylum Procedures Directive extends the asylum seeker's right to remain to appeal proceedings: «Member States shall allow applicants to remain in the territory until the time limit within which to exercise their right to

34

CJEU judgement of 30 May 2013, C-534/11, Arslan, ECLI:EU:C:2013:343 and judgement of 18 June 2018, C-181/16, Gnandi, ECLI:EU:C:2018:465.

35 Directive 2013/32/EU of the European Parliament and of the Council of 26 June 2013 on common procedures for granting and withdrawing international protection, OJ L 180, 29.6.2013, p. $60-95$. an effective remedy has expired and, when such a right has been exercised within the time limit, pending the outcome of the remedy».

27 In Arslan, the CJEU confirmed that asylum seekers have the right to remain in the territory of the Member State, even if there is no explicit entitlement to a residence permit. It concluded that the Return Directive does not «apply to a thirdcountry national who has applied for international protection [...] during the period from the making of the application to the adoption of the decision at first instance on that application or, as the case may be, until the outcome of any action brought against that decision is known». ${ }^{6}$ However, the Court also recalled that «although Directive 2008/115 is not applicable during the procedure in which an application for asylum is examined, that does not mean that the return procedure is thereby definitively terminated, as it may continue if the application for asylum is rejected». Therefore, the return procedure (if it has been opened already) has to be suspended during the period in which the asylum seeker has a right to stay.

28 In Gnandi, the Court nuanced its position and reflected on whether asylum seekers whose claim was rejected but who have appealed against the negative first instance decision can nonetheless be considered as illegally staying on the territory of a Member State in the sense of Article 2 (1) of the Return Directive. The CJEU comes to the conclusion that nothing in the Return Directive makes the illegality of the stay dependent on the outcome of an appeal

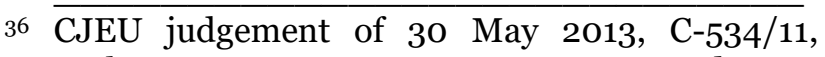
Arslan, ECLI:EU:C:2013:343, paras. 48 and 49. 
against an administrative decision on the ending of a legal stay or on the absence of an authorization to remain pending the outcome of such an appeal. According to the Court, the sole fact that the stay of the person concerned is categorized as being illegal does not infringe the principle of nonrefoulement or the right to an effective remedy. 37 Therefore, a third-country national can be considered as staying illegally, within the meaning of Directive 2008/115, as soon as his application for international protection is rejected at first instance by the determining authority, irrespective of the existence of an authorization to remain pending the outcome of an appeal against that rejection. Thus, the Return Directive does not preclude the adoption of a return decision in respect of a third-country national who has applied for international protection, immediately after the rejection of that application by the determining authority or together in the same administrative act, and thus before the conclusion of any appeal proceedings brought against that rejection, provided that the Member State concerned ensures that all the legal effects of the return decision are suspended pending the outcome of the appeal [...].38

29 Finally, it is important to mention that detention does not deprive an applicant for international protection of the right to remain in the Member State. 39 Detention of asylum seekers is possible according to Article 8 of the Reception Conditions Directive40 or during Dublin proce-

37 CJEU judgement of 18 June 2018, C-181/16, Gnandi, ECLI:EU:C:2018:465, para. 58.

38 CJEU judgement of 18 June 2018, C-181/16, Gnandi, ECLI:EU:C:2018:465, para. 67.

39 CJEU judgement of 15 February 2016, C-601/15 PPU, N., ECLI:EU:C:2016:84, para. 74.

40 Directive 2013/33/EU of the European Parliament and of the Council of 26 June 2013 laying down standards for the reception of applicants dures according to Article 28 of the Dublin III Regulation 41, which also refers to Article 8 of the Reception Conditions Directive. In $N .4^{2}$, the CJEU has recalled that a procedure opened under the Return Directive, «in the context of which a return decision [...] has been adopted, can be resumed at the stage at which it was interrupted, as soon as the application for international protection which interrupted it has been rejected at first instance. Indeed, the Member States must not jeopardise the attainment of the objective which Directive 2008/115 pursues, namely the establishment of an effective policy of removal and repatriation of illegally staying third-country nationals». 43

30 Therefore, the introduction of an asylum application by a person who is subject to a return decision does not cause the return decision to lapse. 44 The obligation to carry out the removal as soon as possible would not be met if the removal were delayed because, following the rejection at first instance of the application for international protection, a return procedure could not be resumed at the stage at

for international protection, OJ L 180, 29.6.2013, p. 96-116.

41 Regulation (EU) No 604/2013 of the European Parliament and of the Council of 26 June 2013 establishing the criteria and mechanisms for determining the Member State responsible for examining an application for international protection lodged in one of the Member States by a third-country national or a stateless person, OJ L 180, 29.6.2013, p. 31-59.

42 CJEU judgement of 15 February 2016, C-601/15 PPU, N., ECLI:EU:C:2016:84. See also Sarah Progin-Theuerkauf / Samah Posse-Ousmane (2016), Rétention d'un demandeur d'asile et droits fondamentaux - L' arrêt J.N. de la CJUE (C-601/15 PPU),

43 CJEU judgement of 15 February 2016, C-601/15 PPU, N., ECLI:EU:C:2016:84, para. 75.

44 CJEU judgement of 15 February 2016, C-601/15 PPU, N., ECLI:EU:C:2016:84, para. 75. 
which it was interrupted, but had to start afresh. 45

These conclusions have been integrated into Article 8 of the Commission's proposal of a Recast Directive. 46

\section{Right to be Heard}

32 An important lacuna of the Directive is that is does not mention (at all) the right to be heard during the return procedure. The CJEU has emphasized in three judgments 47 that the right to be heard is a fundamental right that forms an integral part of the EU's legal order. It is now affirmed not only in Articles 47 and 48 of the Charter of Fundamental Rights, which ensure respect for both the rights of the defense and the right to fair legal process in all judicial proceedings, but also in Article 41 of the Charter, which guarantees the right to good administration. Article 41 (2) of the Charter provides that the right to good administration includes, inter alia, the right of every person to be heard before any individual measure which would affect him adversely is taken. 48

However, it is not necessary to hear a person several times on the same issues. For example, if a decision determining a stay to be illegal and the return decision

45 CJEU judgement of 15 February 2016, C-601/15 PPU, N., ECLI:EU:C:2016:84, para. 76.

46 See infra, V.

47 CJEU judgement of 11 December 2014, C-249/13, Boudjlida, ECLI:EU:C:2014:2431; judgement of O5 November $2014 \mathrm{C}-166 / 13$, Mukarubega, ECLI:EU:C:2014:2336; judgement of 10 September 2013, C-383/13 PPU, G. and R., ECL:EU:C:2013:533.

48 CJEU judgement of 11 December 2014, C-249/13, Boudjlida, ECLI:EU:C:2014:2431, judgement of O5 November 2014 C-166/13, Mukarubega, ECLI:EU:C:2014:2336; judgement of 10 September 2013, C-383/13 PPU, G. and R., ECLI:EU:C:2013:533. are taken separately (see Article $6[6]$ ) and the person concerned was able to present his or her point of view on the question of whether the stay was illegal and whether there were grounds which could, under national law, entitle the authority to refrain from adopting a return decision, or if the return decision is taken directly after a decision on an asylum application, where all reasons for a possible violation of the non-refoulement principle have already been discussed, it is not necessary to hear the person a second time. The CJEU has made clear that «the right to be heard before the adoption of a return decision cannot be used in order to re-open indefinitely the administrative procedure».49

34 Even if the CJEU has clarified the right to be heard, it should be integrated into the Directive to remove any doubt. Also, the consequences of an infringement of the right to be heard should be regulated. Generally, the non-respect of the right to be heard should render the decision invalid insofar as the outcome of the procedure would have been different if the right was respected. $5^{\circ}$

$49 \overline{\text { CJEU judgement of o5 November } 2014 \text { C-166/13, }}$ Mukarubega, ECLI:EU:C:2014:2336, para. 71. See also Sarah Progin-Theuerkauf, Zum Recht auf Anhörung vor Erlass einer Rückkehrentscheidung - Besprechung der Urteile Mukarubega und Boudjlida, Urteilsbesprechung, ASYL $2 / 15,27 \mathrm{ff}$.

50 CJEU judgement of 10 September 2013, C383/13 PPU, G. and R., ECLI:EU:C:2013:533, para. 38. 


\section{Detention and Detention Conditions}

35 As mentioned above, the Return Directive allows detention in order to prepare the return and to carry out the removal process, in particular when there is a risk of absconding or the thirdcountry national concerned avoids or hampers the preparation of return or the removal process. The list is nonexhaustive, as shown by the words «in particular». The Directive neither defines the «risk of absconding» nor what exactly a person has to do to «hamper the preparation of return» (Article 15 [1]). 51 In this context, it is also noteworthy that, unlike Article 8(1)(e) of the Reception Conditions Directive52, the Return Directive does not mention that thirdcountry nationals which are a threat to national security or public order may be detained. However, as the list of detention grounds is not exhaustive, detention would already be possible in those cases. The 2018 Commission proposal for a Recast Return Directive53 now explicitly mentions public order and national security.

The principle of proportionality must be respected, meaning that detention shall be for as short a period as possible and as long as removal arrangements are in progress (Article 15 [1]). When it appears that a reasonable prospect for removal no longer exists, the person has to be released immediately.

51 The Commission's 2018 proposal for a recast contains definitions; however, they are so broad that the situation will not considerably improve, see infra, $\mathrm{V}$.

52 Directive 2013/33/EU of the European Parliament and of the Council of 26 June 2013 laying down standards for the reception of applicants for international protection, OJ L 180, 29.6.2013, p. 96-116.

53 See infra, V.
37 Furthermore, Article 15(3) stipulates that detention shall be reviewed at «reasonable intervals». It is not clear what this exactly means. As to the maximum period of detention of 18 months (Articles 15[5] and [6]), the CJEU has stated that the maximum period cannot be extended. Where the maximum period of detention has expired, the person must be released. 54

38 Asylum seekers may be detained based on the Reception Conditions Directive, which contains a long list of detention grounds. However, it is not impossible that an asylum seeker may also be detained based on the Return Directive. In $N$., the Court has referred to the relevant case-law of the European Court of $\mathrm{Hu}-$ man Rights55, emphasizing that «the existence of a pending asylum case does not as such imply that the detention of a person who has made an asylum application is no longer 'with a view to deportation', since an eventual rejection of that application may open the way to the enforcement of removal orders that have already been made». 56

39 The detention conditions are another critical aspect. According to Article 16 (1), «detention shall take place as a rule in specialized detention facilities. Where a Member State cannot provide accommodation in a specialized detention facility

54 CJEU judgement of 30 November 2009, C357/o9 PPU, Kadzoev, ECLI:EU:C:2009:741, para. 62 and 71. See also Sarah Progin-Theuerkauf, Maximale Dauer der Abschiebehaft nach Art. 15 der EU-Rückführungsrichtlinie, Kommentar zu EuGH, Rs. C-357/o9 PPU, Kadzoev, ASYL 3/10, $31 \mathrm{ff}$.

55 European Court of Human Rights, Nabil and Others v. Hungary, no. 62116/12, § 38 .

56 CJEU judgement of 15 February 2016, C-601/15 PPU, N., ECLI:EU:C:2016:84, para. 79. 
and is obliged to resort to prison accommodation, the third-country nationals in detention shall be kept separated from ordinary prisoners».

40 In Pham, the CJEU has emphasized that even if the person concerned gave their consent, it is not legal to detain her or him together with ordinary prisoners. Member States cannot take account of the wishes of the third-country national concerned. 57

41 In a similar context, the CJEU also held that the requirement of separate detention facilities is imposed upon the Member State as such. Specific administrative or constitutional structures of a Member State do not modify this obligation. If application of the national legislation transposing the Directive is entrusted to authorities falling under a federated state (like in Germany), the State is not obliged to set up specialized detention facilities in each federated state. However, it must be ensured (via agreements on administrative cooperation) that the competent authorities of a federated state that does not have such facilities can provide accommodation for thirdcountry nationals pending removal in specialized detention facilities located in other federated states. 58

\section{Entry Bans}

42 Another complex topic is the entry ban that Member States shall issue together with the return decision in two cases (Article 11): (1.) If no period for voluntary

57 CJEU judgement 17 July 2014, C-474/13, Pham, ECLI:EU:C:2014:2096, para. 22 and 23.

58 CJEU judgement 17 July 2014, C-473/13 und C514/13, Bero and Bouzalmate, ECLI:EU:C:2014:2095, para. 28 et seq. departure has been granted or (2.) if the obligation to return has not been complied with. The length of the entry ban shall not exceed five years, unless the third-country national represents a serious threat to public policy, public security or national security. However, in $N$., the Court accepted a ten-year entry ban without further discussion of these criteria. 59

43 In Filev and Osmani, the Court has made clear that entry bans must automatically be limited in time. It is not compatible with Article 11(2) if a Member States makes the benefit of a limitation of the length of an entry ban subject to the making of an application by the thirdcountry national concerned. ${ }^{60}$ The Court further pointed out that a continuation of the effects of entry bans of unlimited length made before the date on which Directive 2008/115 became applicable is also incompatible with the Directive, unless the person concerned constitutes a serious threat to public order, public security or national security. ${ }^{61}$

44 In Ouhrami, the CJEU stated that the period of application of the entry ban does not begin to run until the date on which the person concerned has actually left the territory of the Member States: «Until the obligation to return is voluntarily complied with or enforced, the illegal stay of the person concerned is governed by the return decision and not by the entry ban. It is only from that

$59 \overline{\text { CJEU judgement of } 15 \text { February 2016, C-601/15 }}$ PPU, N., ECLI:EU:C:2016:84, para. 74.

60 CJEU judgement of 19 September 2013, C297/12, Filev and Osmani, ECLI:EU:C:2013:569, para. 31 .

61 CJEU judgement of 19 September 2013, C297/12, Filev and Osmani, ECLI:EU:C:2013:569, para. 44 . 
point in time that the entry ban produces its effects, by prohibiting the person concerned, for a certain period of time following his return, from again entering and staying in the territory of the Member States». 62

Finally, if a third-country national, who is subject to an entry ban, is parent of a child who is an EU citizen and applies for a residence permit based on family reunification with that child, the Return Directive does not oblige Member States to examine the application.63 However, such an obligation may arise directly from Article 20 TFEU.64 In case the third-country national parent is entitled to a residence permit based on a relationship of dependency with the child, the entry ban has to be withdrawn or suspended. It is irrelevant that the entry ban imposed on the third-country national has become final at the time when he or she submits his application for residence for the purposes of family reunification. ${ }^{65}$ It is further immaterial that the entry ban may be justified by non-compliance with an obligation to return. Where such a ban is justified on public policy grounds, such grounds may permit a refusal to grant that third-country national a derived right of residence under Article 20 TFEU only if it is apparent from a specific assessment of all the circumstances of

62 CJEU judgement of 26 July 2017, C-225/16, Ouhrami, ECLI:EU:C:2017:590, para. 49. See also Sarah Progin-Theuerkauf / Salome Schmid, Beginn der Geltung von Einreiseverboten, Kommentar zu EuGH, Rs. C-225/16, Ouhrami, Urteil vom 26.07.2017, ECLI:EU:C:2017:590, ASYL 4/2017, $20 \mathrm{f}$.

63 CJEU judgement of 8. May 2018, C-82/16, K.A. ECLI:EU:C:2018:308, para. 45.

64 CJEU judgement of 8. May 2018, C-82/16, K.A. ECLI:EU:C:2018:308, para. 62.

65 CJEU judgement of 8. May 2018, C-82/16, K.A. ECLI:EU:C:2018:308, para. 84. the individual case, in light of the principle of proportionality, the best interests of any child or children concerned and fundamental rights, that the person concerned represents a genuine, present, and sufficiently serious threat to public policy. 66

\section{Fate of «Non Removable» Returnees}

46 As mentioned before, the EU Return Directive leaves Member States the choice of either issuing return decisions to illegally staying third-country nationals or of granting a permit to (in other terms: regularize) these persons. ${ }^{67}$ However, there is no obligation to grant a residence permit; this remains a mere possibility. ${ }^{68}$ This also means that the Directive does not contain a right of non-removable returnees to be regularized at a later stage, even if there is no reasonable prospect of removal.69 In the 2017 Return Handbook, the Commission recommends considering regularization based on the assessment of the individual situation of the non-removable returnee and general policy reasons, taking into consideration the following elements:

- Cooperative or non-cooperative attitude of the returnee

- Length of factual stay in the Member State

- Integration efforts made by the returnee

$66 \overline{\text { CJEU judgement of 8. May 2018, C-82/16, K.A. }}$ ECLI:EU:C:2018:308, para. 97.

67 European Commission, Recommendation Establishing a common «Return Handbook » to be used by Member Sates' competent authorities when carrying out return related tasks, C(2017) 6506 - Annex, p. 20 (5.).

68 See (Fn. 66).

69 European Commission, (Fn. 66). - Annex, p. 65 (13.2.). See also CJEU judgement of 5. June 2014, C-146/14, Mahdi, ECLI:EU:C:2014:1320, para. 87 and 88 . 
- Personal conduct of the returnee

- Family links

- Humanitarian considerations

- Likelihood of return in the foreseeable future

- Need to avoid rewarding irregularity

- Impact of regularization measures on migration pattern of prospective (irregular) migrants

- Likelihood of secondary movements within the Schengen area.

When reading the list, it becomes evident that the situation of long-term nonremovable returnees is highly unsatisfactory, as there is no uniform approach as to when and under which circumstances they can be regularized. It should be emphasized in the Directive (and the Handbook) that regularization should at least be considered in the light of Article 8 ECHR (right to private life), as interpreted by the European Court of Human Rights, according to which regularization must become possible after a certain (long) lapse of time, considering the individual situation of the irregular migrant, especially his or her integration into the host society, family ties and difficulties to re-integrate into his or her country of origin. $7^{\circ}$ It would be better to define at least some of these criteria in the Directive, in order to harmonize this aspect and not to create a reason to «forum shop» in the EU Member States.

\section{The 2018 Proposal for a Recast}

48 On 9 September 2018, the EU Commission published a proposal for a recast of the EU Return Directive (in the following: Recast Directive). ${ }^{71}$ In the explanatory memorandum accompanying the proposal, the Commission states that, despite many efforts, «there has been little progress in increasing the effectiveness of returns». The Commission argues that, in order to achieve a more effective and coherent European return policy, an «urgent adoption of a targeted recast of the Return Directive is necessary». The proposed modifications are not supposed to change the scope of the Directive «nor affect the protection of rights of the migrants that currently exist».

49 The proposed changes concern nine different aspects:

1. The «risk of absconding» will be defined in Article 6 of the Recast Directive. The list contains sixteen (!) different criteria and mentions situations like the lack of documentation proving identity, the lack of a reliable address, the lack of financial resources or illegal entry into the territory of the Member States. The list is non-exhaustive.

2. The Recast Directive will introduce an obligation by the third-country nationals to cooperate, similar to the obligation that exists in asylum procedures (Article 7).

${ }_{71} \overline{\text { European Commission, Proposal for a Directive }}$ of the European Parliament and of the Council on common standards and procedures in Member States for returning illegally staying third-country nationals (recast), COM(2018) 634 final. 
3. Member States will be obliged to issue a return decision immediately after a decision rejecting or terminating the legal stay. If the decision is a rejection of an application for international protection, the enforcement of the return decision is suspended until the rejection becomes final (Article 8).

4. It is not mandatory anymore to grant a period for voluntary departure of at least seven days. The proposal establishes a number of cases in which there will be no period for voluntary departure (Article 9).

5. It will be possible to impose an entry ban without issuing a return decision, when an illegally staying thirdcountry national is detected for the first time when leaving the European Union (Article 13).

6. Member States have the obligation to install a national return management system (Article 14).

7. Appeals against return decisions will have to be lodged within 5 days. If there is a risk for a breach of the nonrefoulement principle, the appeal must have automatic suspensive effect. It is possible to temporarily suspend the enforcement of a return decision; the decision on temporary suspension must be made within 48 hours as a rule. If the return decision is a result of a negative decision on an application for international protection (which was already subject to a judicial remedy), there is only one level of judicial remedy (Article 16).

8. Detention is possible if the thirdcountry national is a threat to public order or national security. National legislation must provide for not less than three months as an initial minimum period for detention (Article 18).

9. There are simplified rules for thirdcountry nationals who were subject to asylum border procedures. The decision will be issued by a simplified form, appeals must be lodged within 48 hours and a dedicated ground for detention is introduced. Detention is possible for a maximum period of four months under the border procedure for returns. However, if the return decision is not enforced within these four months, the third-country national may be further detained if one of the conditions in the general rules on detention is fulfilled. The maximum period of detention of the new Article 18 (currently Article 15) must be respected.

5o The proposed changes all go in the same direction: They aim at deterring irregular migrants as much as possible. Many of the suggested «improvements» have a high potential for fundamental rights violations:

1. The broad definition of the «risk of absconding» (especially the criteria relating to documents, financial resources or a reliable address) will lead to the situation that almost every irregular migrant poses such a risk and can therefore be detained. It is not comprehensible how Article 6 will create more legal certainty. In fact, it will result in a systematic detention of all irregular migrants. ${ }^{72}$ In short, it is likely to cause human rights violations.

$72 \overline{\text { See also Steve Peers (2018), Lock 'em up: the }}$ proposal to amend the EU's Returns Directive, 12 September 2018, 
2. The introduction of a minimum period of detention of three months (Article 18) goes in the same direction and might violate the principle of proportionality, as there might be less room for an individual assessment of the adequate period of detention.

3. The shorter periods for appeals, the possibility to impose entry bans on persons who did not receive a return decision, the abolition of a minimum period for voluntary departure and the new border procedure will also further weaken the situation of irregular migrants.

51 What is even more disappointing is that most of the problems of the existing Return Directive described above ${ }^{73}$ will not be tackled by the Recast Directive. The only problem that is half-heartedly addressed is the relationship between return procedures and asylum procedures. All the other problematic issues remain untouched. Therefore, the Recast Directive is unable to really lead to a more uniform application of the rules governing returns, nor will there be more legal security as to the protection of fundamental rights of irregular migrants.

\section{Conclusion}

52 The analysis of CJEU case-law has shown that the Return Directive is too vague and incomplete in important aspects. These lacunae considerably increase the danger of an inconsistent transposition of the Directive and of fundamental rights violations in the Member States. Even if one considers an interpretation and application in accordance with fun-

73 Supra, IV. damental rights to be possible under the current regime 74 , it cannot be denied that Member States have to make a considerable effort to find out how exactly to be in line with fundamental rights when applying the Directive. It is evident that this is not an ideal situation for an instrument aiming at a certain harmonization and comparability between the Member States. For the time being, the case-law of the CJEU has to be constantly monitored in order to be aware of how to best implement the Directive.

53 As to the regularization of irregular migrants, the current regime unfortunately does not go beyond applicable Public International Law: The principle of state sovereignty clearly allows for regularization at any time. The Directive consequently does not create any additional obligations of the Member States to regularize irregular migrants. Even worse: It can be argued that the Directive seems to accentuate the difficult situation of longterm irregular migrants, as it does not explicitly foresee a possibility to obtain a residence permit if the return procedure was unsuccessful. The only way out of a situation of protracted irregularity is via the application of Article 8 ECHR (as interpreted by the European Court of $\mathrm{Hu}-$ man Rights).

54 For all these reasons, it can be argued that the Directive has not really achieved its aim of setting up a fair and transparent regime for returns. The Recast Directive will not be able to fulfill these objectives, either. On the contrary, it will further weaken the legal position of irregular migrants and create more potential for fundamental rights violations.

74 Francesco Maiani (2009), (Fn. 10), 289, 314. 
55 A «real» reform of the EU Return Directive, taking into account the detected problems, would not only be helpful to remove the existing gaps and improve the situation of returnees, it would also provide a better framework for the Member States obliged to implement it.

56 It is therefore necessary to not only send irregular migrants back to where they came from. Instead, the EU legislator should also go back to the start and think of an alternative system to the existing one. It is a matter of fact that the current system based on deterrence does not work, so it could be worth trying a more liberal one: Returns are indeed part of a credible immigration policy, but more possibilities to legally migrate and an EU-wide standard regarding regularization also help reduce irregular migration and exploitation. A change of paradigm in EU migration policy might therefore be the solution to a lot of problems. 